\title{
Estimation of liquefaction of sandy soil in District 7, HCMC, Vietnam
}

- Pham Minh Tuan

- Vo Dai Nhat

University of Technology, VNU-HCM

(Manuscript Received on August 12 ${ }^{\text {th }}, 2014$; Manuscript Revised November 19 $9^{\text {th }}, 2014$ )

\section{ABSTRACT:}

As one of the secondary geologic hazards of Earthquakes, liquefaction has been researched since 1960s in USA, Japan, etc. Scientists researched many methods and field tests used to determine liquefaction. This paper uses the results of Standard Penetration Tests (SPT) and NCEER (USA Nation Center for Earthquake Engineering

Keywords: Liquefaction, SPT, Earthquake, Magnitude, NCEER, Sandy Soil.

\section{INTRODUCTION}

Following disastrous earthquakes in Alaska and in Niigata, Japan in 1964, Seed and Idriss (1971) developed and published the basic "simplified procedure". That procedure has been modified and improved periodically since that time, primarily through landmark papers by Seed (1979), Seed and Idriss (1982), and Seed et al. (1985). In 1985, Professor Robert V. Whitman convened a workshop on behalf of the National Research Council (NRC) in which 36 experts and observers thoroughly reviewed the state-ofknowledge and the state-of-the-art for assessing liquefaction hazard. The liquefaction refers to the phenomena of seismic generation of large pore-water pressures and consequent softening of granular soils. The liquefaction is very dangerous phenomenon such as increase of shear strength, soil deformation, and ground failure. "The simplified procedure" (named NCEER in this paper) was developed from empirical evaluation of field observations, field tests and laboratory tests data. When liquefaction occurs, sand layers soften quickly, allowing large cyclic deformations to occur. In loose materials, the softening is also accompanied by a loss of shear strength that may lead to large shear deformations or even flow failure under moderate to high shear stresses, such as a foundation or slope. In this report, the
Research) methods to evaluate the liquefaction in District 7, Ho Chi Minh City. The result showed that $50 \%$ wards in the study area occurs this phenomenon. The map of liquefaction zone was made and it can be used to construction management. liquefaction was evaluated in District 7, HCMC.

\section{OVERVIEW OF LIQUEFACTION}

The liquefaction is one of the secondary geological hazards of earthquake. What is happened with the soil in places where liquefaction occurred? When sand and water are saturated, the seismic vibration occurred, the water spills out quickly, the pore-water pressure becomes high enough to reduce apart or even all the soil's weight. In this content, liquefaction refers to the phenomena of seismic generation of large pore-water pressure and softening of granular soils.

Nowadays, many researches show that the liquefaction occurred by earthquake is only appeared in saturated sand, mud is considered as liquid (depend on the water content). Liquefaction or softening in clay is very different because of the deformation structure.

In 1971, the first research of liquefaction was done by Seed \& Idriss, after the huge damage of the earthquake in Alaska (America) and Niigata (Japan) in 1964. These scientists showed out the method named "simple method" to evaluate the liquefy ability. In 1996, in America, the calculation method of liquefaction was corrected, here and after called NCEER (USA Nation Center for Earthquake Engineering Research). Beside,

\section{Trang 40}


there were some researches in Japan, here called "Standard Specification for Highway Bridge". In Vietnam, there are not many researches about the liquefaction by earthquake. One of several researches is The evaluation the liquefy ability at Tycoon Factory, Dung Quat, Quang Ngai, this report was written by Nguyen Viet Ky and Dau Van Ngo. In addition, there are some works about the earthquake and the liquefaction in Hanoi and Ho Chi Minh City (Dist. 1 \& 3) researched by Nguyen Hong Phuong and Nguyen Viet Ky. There are some influences of the earthquake liquefaction such as ground shake, sparkling sand(the conical small craters), impacting on settlement foundation, destabilizing the building. Some methods that prevent the damage of this phenomenon were given, such as a cohesive method, sand replacement or using piles. However, these methods are useful in a small zone. To reduce the damage, we need macro management and planning method.

\section{USING LIQUEFACTION EXPERIMENTS}

Prediction of the soil liquefaction can be calculated by several methods. Various laboratory testing have been used such as the triaxial test, the simple shear test and the torsional shear test; however, these tests have to be operated under cyclic loading conditions. Based on researches of Seed and Lee (1966), the resistance to liquefaction can be evaluated by using the stress ratio $\tau_{1} / \sigma_{c}$ relating to shear stress $\left(\tau_{1}\right)$ and initial confining pressure $\left(\sigma_{c}\right)$. Another factors affecting the liquefaction is the relative density, $D_{r}$ as

$$
D_{r}=\frac{e_{\max }-e}{e_{\max }-e_{\min }}
$$

where $e$ is the void ratio, $e_{\max }$ and $e_{\min }$ are the void ratios in the loosest and densest states. By using the triaxial test in 10 cycles of load repetition, Tanimoto shows the relation between $\mathrm{D}_{\mathrm{r}}$ and $\tau_{1} / \sigma_{\mathrm{c}}$ as

$$
\tau_{1} / \sigma_{c}=4.6 \times 10^{-3} \times D_{\mathrm{r}}
$$

This result is very useful to evaluate the liquefaction because of the experimental condition in Vietnam. Another method is used to investigate liquefaction is In-Situ tests. Blasting Test and Vibratory Pile Driving Test are used to improve the liquefaction prediction. According to Kenji Ishihara, one of the difficulties in making correct predictions based on laboratory test data lies in the fact that the field behavior of sandy sand, as has been inferred from Standard penetration test, is not necessarily well correlated with the pore pressure development characteristics of In-Situ sand deposits.

Table 1. The factor of the earthquake's magnitude

\begin{tabular}{|c|c|c|c|}
\hline \multirow{2}{*}{ Name } & \multicolumn{3}{|c|}{ Magnitude } \\
\cline { 2 - 4 } & 5.5 & 6.0 & 6.5 \\
\hline $\begin{array}{c}\text { Seed } \\
\text { \&Idriss }\end{array}$ & 1.43 & 1.32 & 1.19 \\
\hline Idriss & 2.20 & 1.76 & 1.44 \\
\hline Arango & 2.20 & 1.65 & 1.40 \\
\hline $\begin{array}{c}\text { Andrus \& } \\
\text { Stokoe }\end{array}$ & 2.80 & 2.10 & 1.60 \\
\hline $\begin{array}{c}\text { Youd \& } \\
\text { Noble }\end{array}$ & 2.86 & 1.93 & 1.34 \\
\hline
\end{tabular}

Table 2. The properties of soils in District 7

\begin{tabular}{|c|c|c|}
\hline No & Name & Thickness $(\mathrm{m})$ \\
\hline 1 & Leveling sand & $1.5-4.0$ \\
\hline 2 & Mud, gray, flowing state & $7.0-21.0$ \\
\hline 3 & Clay, plastic & $6.8-23.0$ \\
\hline 4 & Sand, sandy clay stiff state & $2.6-14.1$ \\
\hline 5 & Clay, stiff state & $3.5-15.0$ \\
\hline 6 & $\begin{array}{c}\text { Sand, Sandy clay, stiff to } \\
\text { hard state }\end{array}$ & $2.0-40.0$ \\
\hline
\end{tabular}

\section{NCEER METHOD}

In general, NCEER method compares between cyclic resistance ratio(CRR) and the cyclic stress ratio(CSR), this method also needs to determine the magnitude scaling factors(MSF)in the study area to calculate the coefficient of FS. After calculating, if the value of FS is less than 1.7, the liquefaction can occur.

$$
\mathrm{FS}=\left(\mathrm{CRR}_{7.5} / \mathrm{CSR}\right) \cdot \mathrm{MSF}
$$

Seed and Idriss (1971) formulated the following equation for calculation of the cyclic stress ratio:

$$
C S R=0.65 \frac{\alpha_{\max }}{g} \frac{\sigma_{v o}}{\sigma_{v o}^{\prime}} r^{d}
$$

where $a_{\max }=$ peak horizontal acceleration at the ground surface generated by the earthquake $\left(\mathrm{m} / \mathrm{s}^{2}\right) ; g=$ acceleration of gravity; $\sigma_{\mathrm{vo}}$ and $\sigma^{\prime}$ vo are total and effective vertical overburden stresses $(\mathrm{kPa})$, and $r_{d}=$ stress reduction coefficient.

The cyclic resistance ratio (CRR) can be determined 
by field tests as standard penetration test(SPT); cone penetration test (CPT); shear wave velocity $\left(\mathrm{V}_{\mathrm{s}}\right)$; Becker penetration test(BPT). SPT and CPT are often chosen because of their popularities. In term of Vietnam, the SPT results are preferred.

$$
\begin{gathered}
\mathrm{CRR}_{7.5}=\left[1 /\left(34-\mathrm{N}_{60}\right)+\mathrm{N}_{60} / 135+50 /\left[10 \mathrm{~N}_{60}+45\right]^{2}\right. \\
-1 / 200
\end{gathered}
$$

\section{$\mathrm{N}_{60}=\mathrm{N}_{\mathrm{m}} \mathrm{C}_{\mathrm{N}} \mathrm{C}_{\mathrm{E}} \mathrm{C}_{\mathrm{B}} \mathrm{C}_{\mathrm{R}} \mathrm{C}_{\mathrm{S}}$}

where $\mathrm{N}_{\mathrm{m}}=$ measured standard penetration resistance; $\mathrm{C}_{\mathrm{N}}=$ factor to normalize $\mathrm{N}_{\mathrm{m}}$ to a common reference effective overburden stress; $\mathrm{C}_{\mathrm{E}}=$ correction for hammer energy ratio; $\mathrm{C}_{\mathrm{B}}=$ correction factor for borehole diameter; $\mathrm{C}_{\mathrm{R}}=$ correction factor for rod length; and $\mathrm{C}_{\mathrm{S}}=$ correction for samplers with or without liners. $\mathrm{CRR}_{7.5}$ is the cyclic resistance ratio for magnitude 7.5 earthquakes. We must determine the magnitude scaling factors to apply this method to other earthquakes. Table1shows the values converted according to some researchers.

In addition, to make more accurate results, we should also assess the impact of overburden on the soils studied. This value is measured by the coefficient $\mathrm{K}_{\sigma}$. $\mathrm{K}_{\alpha}$.

$$
\mathrm{FS}=\left(\mathrm{CRR}_{7.5} / \mathrm{CSR}\right) . \mathrm{MSF} \cdot \mathrm{K}_{\sigma} \mathrm{K}_{\alpha}
$$

$\mathrm{K}_{\sigma}$ is a factor calculated from effective overburden pressure, and atmospheric pressure - these factors had to measured in the same unit. Furthermore, the value of $\mathrm{K}_{\sigma}$ is depended on the density of soil. On the other hand, a corre

To calculate capacity liquefied for a particular area, follow the order: Step 1 - Determine the soil data; Step 2 - Calculate the value of CSR causing liquefaction; Step 3 - Calculate the value of CRR causing soil resistance; Step 4 - Assessment results; Step 5 Summary of findings.

\section{THE DETAILS OF REASEARCH ZONE}

District 7, HCMC has good infrastructure, it's famous by Tan Thuan industry, Phu My Hung residence and various modern buildings. In geological view, District 7 is a low land. Before urbanized, this area was a marsh. The topsoil is mainly mud, some places up to $23 \mathrm{~m}$ thick. Today, because of construction demand, subsoil layers in Dist. 7 were leveled by sand. The soil characteristics were shown in Table 2. In this report, the author only evaluated the liquefaction of natural soils that SPT values from 1 to 30 . The researches about the leveling sand liquefaction will be done in the future.

Sand distributes of $90 \%$ area in Dist. 7, the soil's thickness changes from 2.6 to $14.1 \mathrm{~m}$. In this soil,the moisture is $18.23 \%$; the unit weight is $2.01 \mathrm{~g} / \mathrm{cm}^{3}$, the cohesion is $0.07 \mathrm{~kg} / \mathrm{cm}^{2}$.

In many researches, HCMC has some faults causing earthquakes. District 7 located in the zone that could be happened magnitude 5.5 earthquakes. As the earthquake occurs, the vibrations will be appeared. Then, the soil is subjected to cyclic shear deformations. In the simplified procedure, peak horizontal acceleration $\left(a_{\max }\right)$ is used to characterize the intensity of ground shaking. Following the database of $\mathrm{V}_{\mathrm{s}}$ (Vietnam Standards), $a_{\max }$ has value of $0.0856 \mathrm{~m} / \mathrm{s}^{2}$ in District 7.

\section{RESULTS OF THE LIQUEFACTION IN DISTRICT 7, HCMC}

There are 138 boreholes calculated in District 7 . Seventy boreholes have enough data to calculate and the liquefaction can occur in 25 boreholes. Following the results, Phu Thuan ward is the most dangerous area (15/25), and the next is Tan Thuan Dong ward. These points were located in the map, the Surfer software (Kriging method) was used to interpolate and map. In this map (Fig. 1), we can see the liquefied area easily.

After finishing the determination, and synthetizing the result, we realized that most of the soils which can be liquefied are not deep (from 13.5 to $30 \mathrm{~m}$ ). In there, the overburden stress has values from 77.61 to $148.4 \mathrm{kPa}$. The SPT value is not high, about $3-15$. Almost, the liquefied soils were fine and clean sand. These experiments are useful for designing building's foundation. 


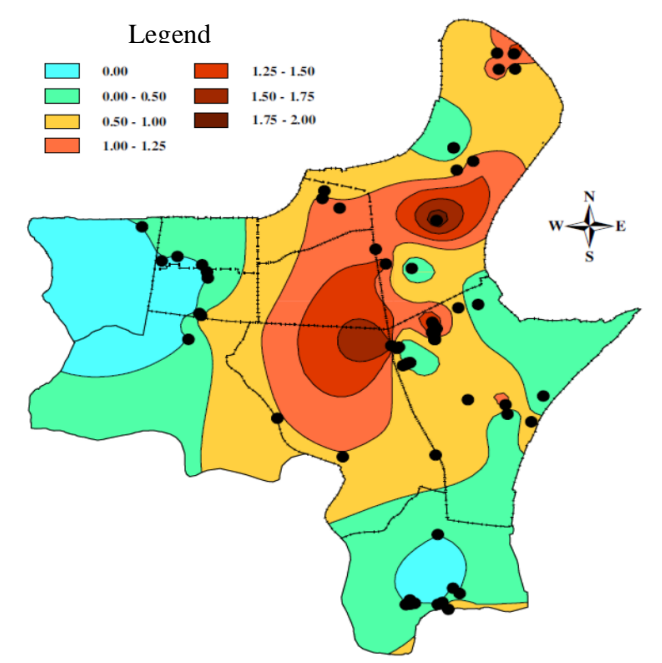

Fig.1. The liquefied soil map in District 7

\section{Example of the Calculator}

Author chose the borehole named "PMT" to take an example. The location of this borehole is in Phu Thuan, its depth is about $64.50 \mathrm{~m}$. The SPT's results were given by $\mathrm{XY}-100$ drilling machine. The properties of soils in the area were used to determine initial state. Then, the author calculated CSR and CRR, the results depend on "N" (SPT) and the earthquake's characteristics (magnitude 5.5). MSF factor evaluated, this value is 1.43 (Seed \& Idriss). Finally, the author compared CRR and CSR by determining FS. The liquefaction occurred in layers 3 and 4 , because the FS was less than 1.7.

The calculation results are shown in Fig. 1, the regions where liquefaction can occur are located at Binh Thuan, Phu Thuan, Tan Thuan Tay, Tan Thuan Dong and Tan Phu wards. The ability of liquefaction in calculation in Tan Thuan Dong ward is the highest and the ability of liquefaction in interpolation in Binh Thuan ward is the highest. These areas need to have treatment with care.

\section{CONCLUSIONS}

NCEER method is useful to evaluate the ability liquefaction in Dist. 7, Ho Chi Minh City. There are many experiments can be used, but SPT with various data source was chosen to calculate. The earthquakes will be occurred in Dist. 7 with the maximum level (magnitude 5.5); therefore, the liquefaction can be occurred. Based on the statistic and analysis calculation results, we can determine the measurements of the areas that can control this dangerous phenomenon.The disadvantage of this result is that the study has just only calculated by the theory. To enhance the accuracy of the results, it needs to test the soils by more methods, or modeling the liquefaction in the real condition of Dist.7. Although the data used to calculate is quite various, the data source needs to supplement the SPT in leveled sand, filling soils, as well as the experiment about the grain of soils to have the more exactly results. Finally, it also needs to add some field tests in Binh Thuan ward because this area has a lot of liquefield values that calculated by interpolation.

The liquefaction can be occurred without the earthquakes? Basically, the liquefaction only needs the vibration; there are many reasons caused vibration; for example, the loading of the running truck. It's exciting to research in the near future.

\begin{tabular}{|c|c|c|c|c|c|c|}
\hline \multicolumn{7}{|c|}{ Table 3. The results of the evaluation in PMT borehole } \\
\hline No & Name of soil & $\begin{array}{c}\text { Unit weight } \\
\left(\mathrm{g} / \mathrm{cm}^{3}\right)\end{array}$ & $\begin{array}{c}\text { Cohesion } \\
\left(\mathrm{kG} / \mathrm{cm}^{2}\right)\end{array}$ & $\begin{array}{c}\text { Friction angel } \\
(\text { degree })\end{array}$ & \multirow{2}{*}{ CSR } & CRR \\
\hline 1 & Leveling sand & - & - & - & - & - \\
\hline 2 & Mud, gray, flowing state & 1.50 & 0.080 & $5^{\circ} 10$ & 0.0655 & 0.049 \\
\hline 3 & Clay, plastic & 1.89 & 0.035 & $20^{\circ} 00$ & 0.0753 & 0.073 \\
\hline 4 & Sand, sandy clay stiff state & 1.88 & 0.200 & $24^{\circ} 30$ & 0.0701 & 0.063 \\
\hline 5 & Clay, stiff state & 1.94 & 0.040 & $21^{\circ} 10$ & 0.0657 & 0.060 \\
\hline 6 & $\begin{array}{c}\text { Sand, Sandy clay, stiff to hard } \\
\text { state }\end{array}$ & 1.99 & 0.290 & $24^{\circ} 00$ & 0.0641 & 0.071 \\
\hline
\end{tabular}




\section{Đánh giá khả năng hóa lỏng đất nền do động đất trong vác tầng đất loại cát tại Quận 7, Tp. Hồ Chí Minh, Việt Nam}

- Phạm Minh Tuấn

- Võ Đại Nhật

Trường Đại học Bách khoa, ĐHQG-HCM

\section{TÓM TÁT:}

Là một trong những tai biến thứ sinh của động đất, hóa lỏng đất nền đã được nghiên cứu từ những năm 1960 tại Mỹ và Nhật Bản. Các nhà khoa học đã đưa ra nhiều phương pháp đánh giá và tính toán khả năng hóa lỏng khác nhau. Bài báo này sử dụng các kết quả từ thí nghiệm Xuyên Tiêu Chuẩn (SPT) áp dụng vào lý thuyết NCEER (Trung tâm Quốc gia nghiên cứu về động đất của

Hoa Kỳ) để đánh giá khả năng hóa lỏng trong các lớp đất loại cát tại Quận 7, Tp. Hồ Chí Minh. Kết quả cho thấy $50 \%$ các phường trong khu vực nghiên cứu có khả năng xảy ra hiện tượng này. Bản đồ của khu vực hóa lỏng đã được xây dựng và nó có thể được áp dụng trong các công tác xây dựng và quy hoạch tại địa phương.

Từ khóa: Liquefaction, SPT, Động đất, Magnitude, NCEER, Đất loại cát.

\section{TÀI LIỆU THAM KHẢO}

[1]. Youd T. L, Liquefaction resistance of soils, Summary report from the 1996 NCEER and 1998 NCEER/NSF workshops on evaluation of liquefaction resistance of soils (2001)

[2]. Seed H. B, Simplified Procedure for Evaluating Soil Liquefaction Potential, Journal of the Soil Mechanics and Foundations Division, Vol. 97, No. 9, pp. 1249-1273 (1971)

[3]. Youd T. L, Mapping Liquefaction-Induced Ground Failure Potential, Journal of the Geotechnical Engineering Division, Vol. 104, No. 4, pp. 433-446 (1978)

[4]. Seed H. B, Landslides during earthquakes due to liquefaction, Journal of Soil Mechanics \& Foundations Div (1968)

[5]. Richard P. R, Liquefaction behavior evidence, prediction and prevention, Journal of Soil Mechanics \& Foundations Div (2001)

[6]. Howell D. A, Liquefaction and Cyclic Mobility of Saturated Sand, Journal of the Geotechnical Engineering Division, Vol. 101, No. 6, pp. 551569 (1975)
[7]. Seed H. B \& Lee, K. L, Liquefaction of saturated sand during cyclic loading, Journal of Soil Mechanics \& Foundations Div (1966)

[8]. Peacock, W H, Sand liquefaction under cyclic loading simple shear conditions, Journal of Soil Mechanics \& Foundations Div (1968)

[9]. Ishihara K. Liquefaction of subsurface soils during earthquakes, Journal of Disaster Research Vol.1 No.2 (2006)

\section{Trang 44}

